\title{
SEISMIC VULNERABILITY ASSESSMENT OF A MASONRY BUILDING LOCALLY STRENGTHENED
}

\author{
Alice Podavka ${ }^{1}$ \\ Ildi Cismasiu ${ }^{2}$ \\ Sorin $\operatorname{Dan}^{3}$
}

UDK: 624.042 .7

DOI:10.14415/konferencijaGFS2017.004

Summary: As it is known, Portugal is a country prone to seismic activity. After the 1755's devastating Lisbon Earthquake, the city's downtown was rebuilt with "Pombalino" masonry buildings. This type of buildings includes a three-dimensional timber structure enclosed in masonry walls aiming to provide seismic resistance to these structures.

Most of these buildings need structural strengthening interventions and therefore the main goal of this paper is the seismic vulnerability assessment of the structural performance of an existing "Pombalino" masonry building modified by local strengthening systems.

The structure was modeled in the 3Muri software based on the non-linear equivalent frame model approach. The in-plane capacity curves were found out by incremental static (pushover) analysis, to establish the buildings global structural performance.

Keywords: old masonry building, 3Muri software, strengthening, seismic assessment

\section{INTRODUCTION}

The history of Lisbon is marked by the violent earthquake of 1755 which completely devastated the central area of Lisbon, being necessary to take emergency measures that unleashed the process of the reconstruction of the capital. Lisbon Downtown, near Tagus River, was the most destroyed area of Lisbon and was rebuilt following an urban plan. The need of a fast rebuilt and the fear of another earthquake led to the enforcement of new construction rules based on the experience learned from the collapsed buildings due to the earthquake, aiming to provide seismic and fire resistance to the new constructions. The new constructions built according to these rules are named 'Pombalino' Buildings, after the 'Marquês de Pombal' the Prime Minister responsible for Lisbon reconstruction [1].

These 'Pombalino' Buildings are masonry buildings which include an anti-seismic provision consisting of an interior three-dimensional braced timber structure named "gaiola" enclosed in masonry walls, aiming to provide resistance to horizontal forces.

\footnotetext{
${ }^{1}$ Alice Jaroslava Podavka, Civ.Eng., Politehnica University Timisoara, Civil Engineering Faculty, Str. T. Lalescu, No. 2, Timisoara, Romania, e-mail: p.jaroslava@yahoo.co.uk

${ }^{2}$ Ildi Cismasiu, Assist.Prof.Dr.Civ.Eng., Nova University Lisbon, Department of Civil Engineering, Campus da Caparica, Caparica, Portugal, e-mail: ildi@fct.unl.pt

${ }^{3}$ Sorin Dan, Assoc.Prof.Dr.Civ.Eng., Politehnica University Timisoara, Department of Civil Engineering and Building Services Engineering, Str. T. Lalescu, No. 2, Timisoara, Romania, tel: +40256403933, e-mail: sorin.dan@upt.ro
} 
Although they exceeded a long time ago their life span for which they were designed, many of them are still in service, while the minimum requirements of comfort and safety are nowadays much more demanding, which leads to the necessary adaptation of housing to new regulatory requirements through a proper rehabilitation.

Figure 1 presents structural details of 'Pombalino Buildings, where the presence of the "gaiola" enclosed in masonry interior walls is identified. The other interior walls (partition walls) are wooden panels that should not be considered as having structural functions. Roofs are made with timber truss and ceramic tiles and may include window openings. Floors are timber slabs and can be considered as a flexible diaphragm. Ground floor walls are masonry walls supporting a system of vaults made of blocks of ceramic masonry and stone arches. Foundations include short and small diameter woodpiles connected by a timber grid. The masonry of the exterior walls is made of irregular blocks of calcareous stone and lime mortar having a very low resistance capacity. Masonry infill of the "gaiola" can be stone rubble, some of it from the earthquake-collapsed buildings, or clay bricks, similar to the bricks used at ground floor vaults. It is usual to find both type of masonry at the interior walls [2].
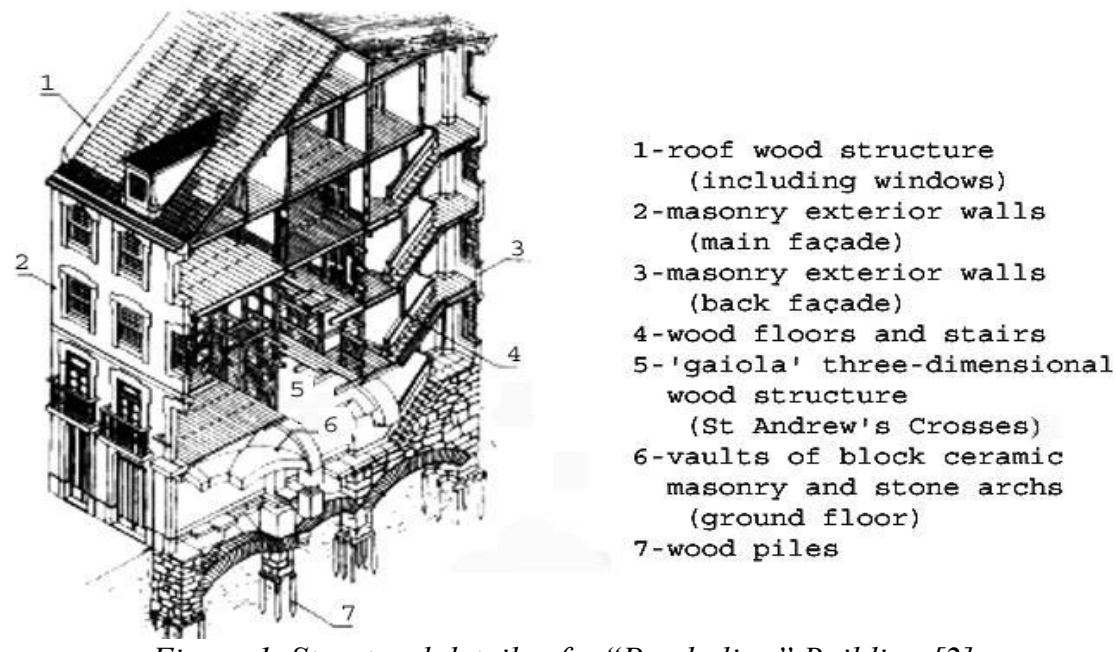

Figure 1. Structural details of a "Pombalino" Building [2]

The "gaiola" three-dimensional timber structure is like a birdcage made of vertical and horizontal elements braced with diagonals named St Andrew's Crosses (Figure 2). The connections between the timber elements of "gaiola" and the exterior masonry walls are performed by iron elements, but sometimes they do not exist.

The main conclusion of the study [1] was that "gaiola" structure increases the building global stiffness because: (1) the frequencies of the building with the "gaiola" are higher than those obtained in the model of the building without this structure, according to the modal configurations; (2) the presence of "gaiola" prevents local vibration modes of the masonry walls because the out-of-plane displacements of each masonry wall (façades and masonry walls between adjacent buildings) no longer occur independently from the rest of the structure; (3) the out-of-plane displacements are equal for parallel masonry walls connected by the same "gaiola" wall. 


\section{$5^{\text {th }}$}

Contemporary achievements in civil engineering 21. April 2017. Subotica, SERBIA
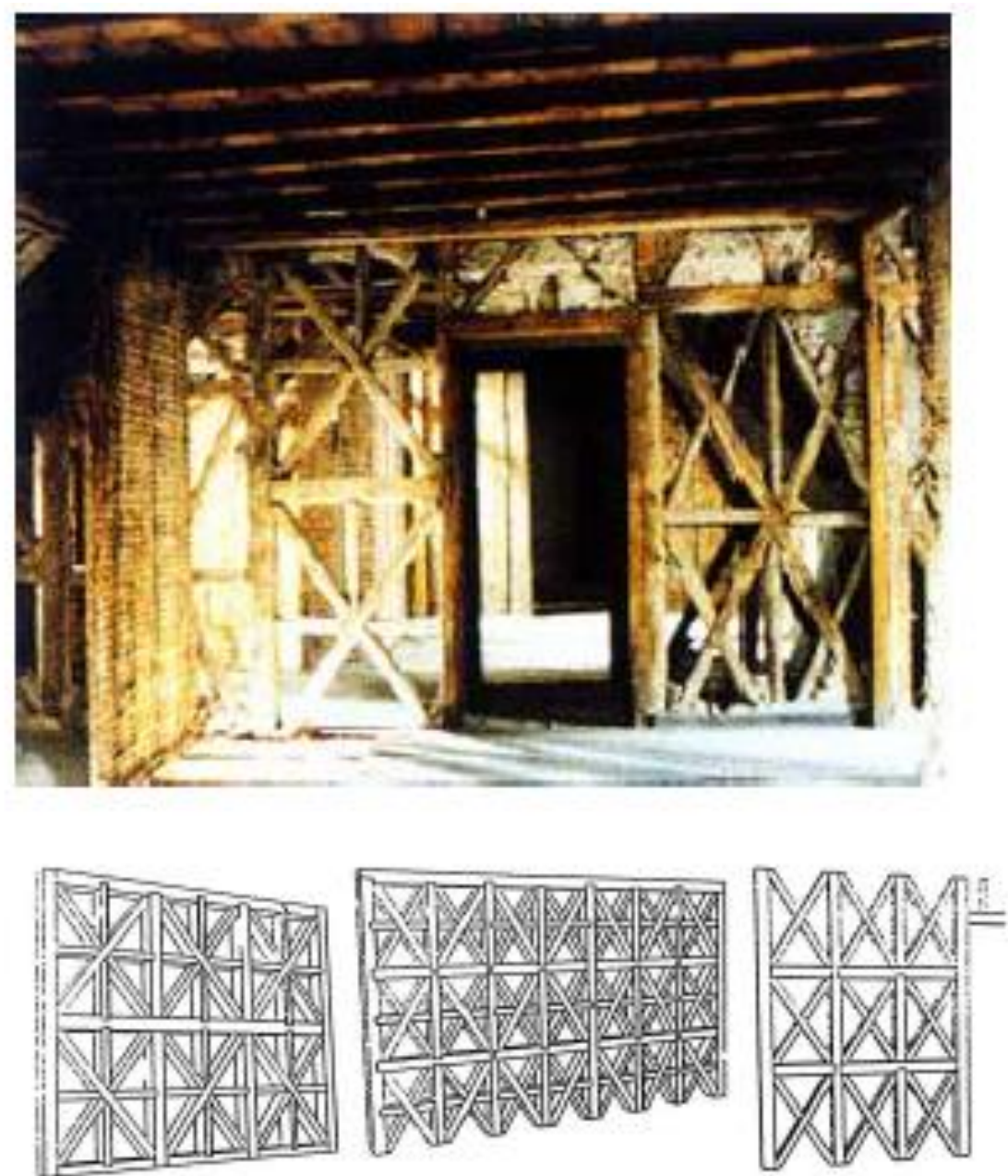

Figure 2. Timber elements of "gaiola" enclosed in masonry interior walls

\section{DESCRIPTION OF THE STUDIED STRUCTURE}

The studied building is located in Rua S. João da Praça no. 29 to 39, in the parish of the Sé, in Lisbon. It was built in the nineteenth century as a typical "Pombalino" building.

Figure 3 presents the façade of the analyzed building. The building has, on the corner of Rua S. João da Praça and Largo Júlio Pereira, 3 levels and at the entrance from of Rua S. João da Praça 4 levels. The horizontal plan of the building is shown in Figure 4. 


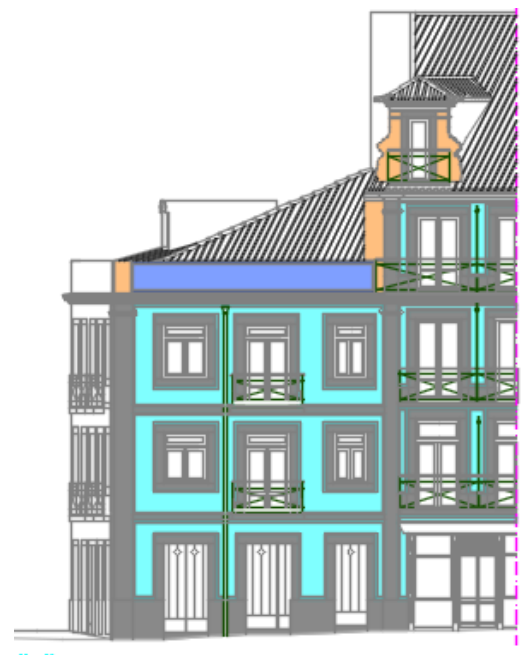

Figure 3. Main façade of the analyzed building

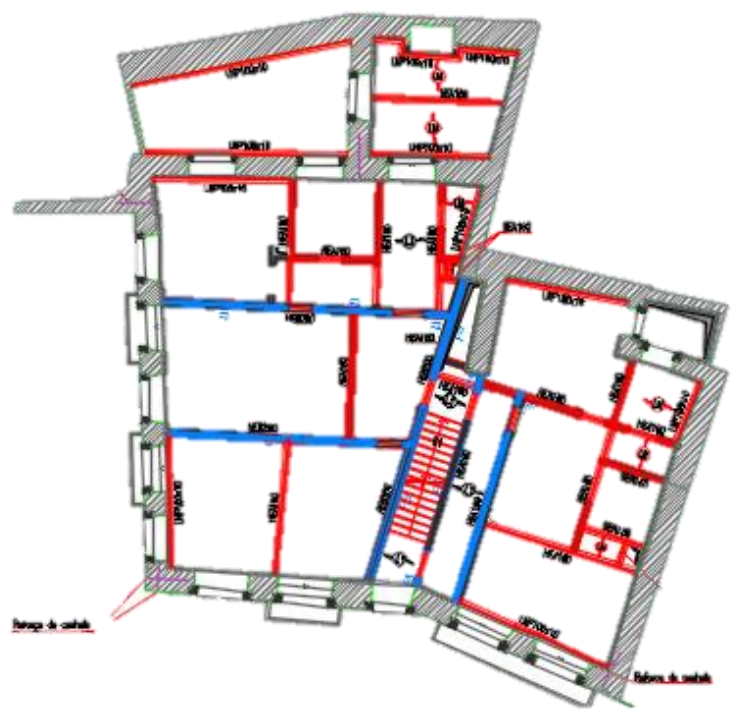

Figure 4. Horizontal plan of the analyzed building

In 2004, it was performed a reinforcement at the foundations of the façade walls, which presented cracks and settlements related to the decompression phenomena of the soil. This intervention consisted in the execution of micro-piles.

After a diagnostic study was performed, evident signs of large deformations, both at the level of the floors and at the level of the frontal walls, were identified. These deformations were caused by two main factors: the first one is related to the phenomenon of decompression of the constituent sands of the foundation soil and the second one is due to the lack of vertical continuity of the frontal alignments at the ground level [4]. 
Contemporary achievements in civil engineering 21. April 2017. Subotica, SERBIA

\section{Strengthening interventions}

The large deformations of the existing floors and the lack of continuity of the vertical alignments at the ground level and the deformations of some frontal walls, led to the decision to completely demolish the interior, but keeping in place the existing masonry walls. Thus the solution involves the reconstruction of the frontal walls needed to support the floors in the same alignments as those already existing and the reconstruction of the existing staircase as it is.

The strengthening solution for the remaining masonry walls was a reinforced concrete plaster which provides the masonry with sufficient resistance to absorb the traction that shows up when the building is subject to seismic actions, in addition to ensure a confinement for vertical loads.

At the top of all maintained walls a reinforced concrete lintel was casted, that serves not only as a belt but also as a support for the new roof cover.

The kitchen and bathroom floors consist of a mixed steel-concrete slab supported by steel profiles HEA 160 linked to the frontal walls while the link to masonry walls is made by LNP100 steel profiles. The rest of the floors are timber slab supported in the same way as the mixed steel-concrete slabs.

The existing roof was also demolished and replaced by a new structure, consisting of main steel profiles and secondary wood elements.

\section{THE EQUIVALENT FRAME MODEL}

In order to assess the seismic global response of the analyzed buildings, a threedimensional model was defined based on the equivalent frame model approach considering the commercial software 3Muri (S.T.A.DATA s.r.l., release 10.9.1.7). Modeling of the building is done by insertion of walls into discrete macro elements. These represent deformable masonry piers and spandrel beams on the level. Rigid nodes are placed in the areas of the masonry that are typically less subject to earthquake damage. Generally, the piers and the spandrel beams are contiguous at the openings, and the rigid nodes are elements that connect the piers and spandrel beams. The mathematical concept behind the use of this element allows the damage mechanism to be found. This is shear damage in the central part, or compression-bending at the edges of the element. In this way, the dynamic damage can be understood in the way that it actually occurs in reality (Figure 5) [5].

The nodes of the model are three-dimensional, with five degrees of freedom. Alternatively, they are two-dimensional nodes with three degrees of freedom. The three-dimensional nodes are used to allow transfer of the actions from one wall to another wall which located transversally to the first. The two-dimensional nodes only have degrees of freedom on the level where the wall is found, allowing transfer of the forces' state between the various points of the wall.

The horizontal structures are modeled with the three node floor elements connected to three-dimensional nodes. They can be loaded perpendicularly to their level using accidental or permanent loads. Seismic actions load the floor along the direction of the level. For this reason, the floor finite element is defined with axial rigidity, but without 
bending rigidity. This is because the main mechanical behavior is important as subjected to horizontal loads due to the seismic action.

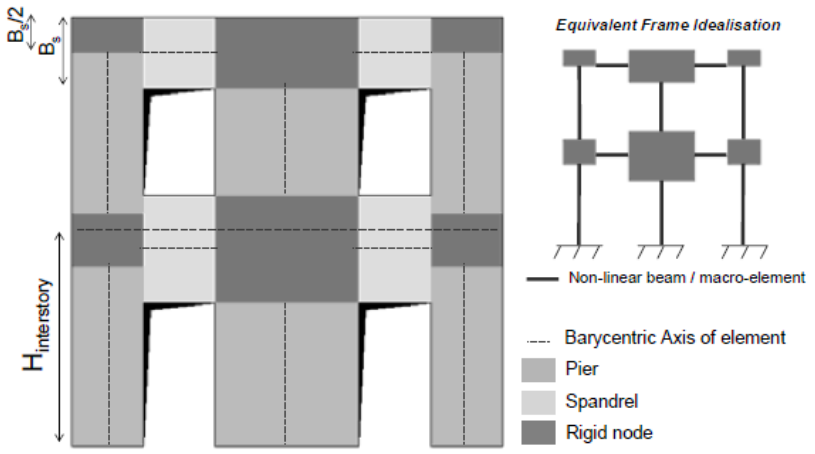

Figure 5. 3Muri software: equivalent frame model idealization [5]

It should be noticed that the frontal walls were similarly defined to masonry walls by masonry macro-elements with very low mechanical properties, because these elements are expected to provide resistance to horizontal actions. This type of modeling does not correspond exactly to reality, but it is accepted if one takes into account the small contribution of these walls to the global structure response. In Figure 6 is presented a 3D model of the structure in 3Muri.

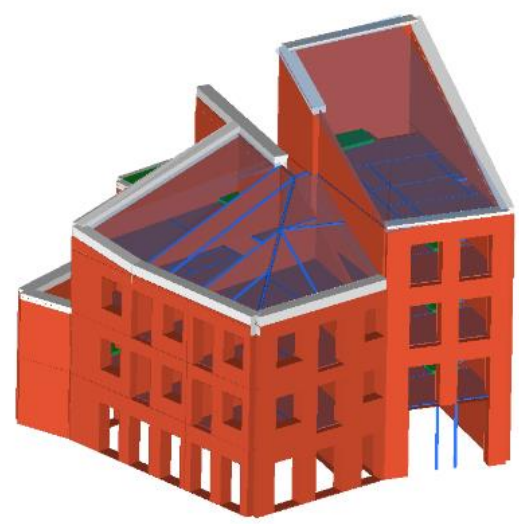

Figure 6. 3D view of the studied structure

In Portugal, for the design and assessment of structures it should be taken into account two types of seismic actions:

- Seismic action type 1 corresponding to a scenario of faraway earthquake;

- Seismic action type 2 corresponding to a scenario of nearby earthquake.

For Lisbon city and for normal residential buildings, for the seismic action type 1 the design ground acceleration is $a_{g}=1.5 \mathrm{~m} / \mathrm{s}^{2}$ and for seismic action type 2 is $a_{g}=1.7 \mathrm{~m} / \mathrm{s}^{2}$. Figure 9 displays the elastic response spectrum for both types of seismic actions. 
Contemporary achievements in civil engineering 21. April 2017. Subotica, SERBIA

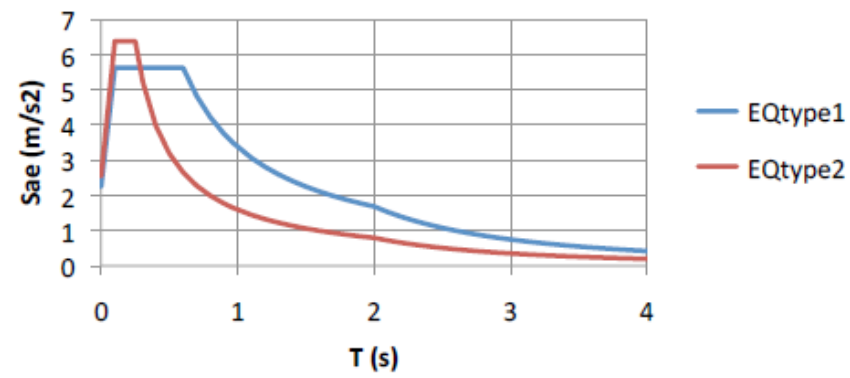

Figure 9. Elastic response spectrum for Lisbon Downtown [6]

It can be seen that, for most of the structural periods' range, the seismic action type 1 is the most demanding, but for the low values periods' range (high frequencies), the seismic action type 2 is the more demanding. The two seismic actions must be considered in the subsequent analyses performed.

\section{CAPACITY CURVES}

The in-plane capacity of the buildings was obtained by non-linear static (pushover) analysis. The analyses were performed for each main direction of the building considering two load patterns: (i) uniform, proportional to the mass; and (ii) pseudo-triangular, proportional to the product between the mass and height. Due to the flexible behavior of the floors, the pseudo-triangular distribution is more accurate than the modal distribution proposed by design codes (proportional to the first vibration mode) as the fundamental vibration mode have a low mass participation. The building pushover curves are plotted in Figure 10 as function of the base shear force $\left(\mathrm{V}_{\mathrm{b}}\right)$ and node control displacement defined at the roof level.

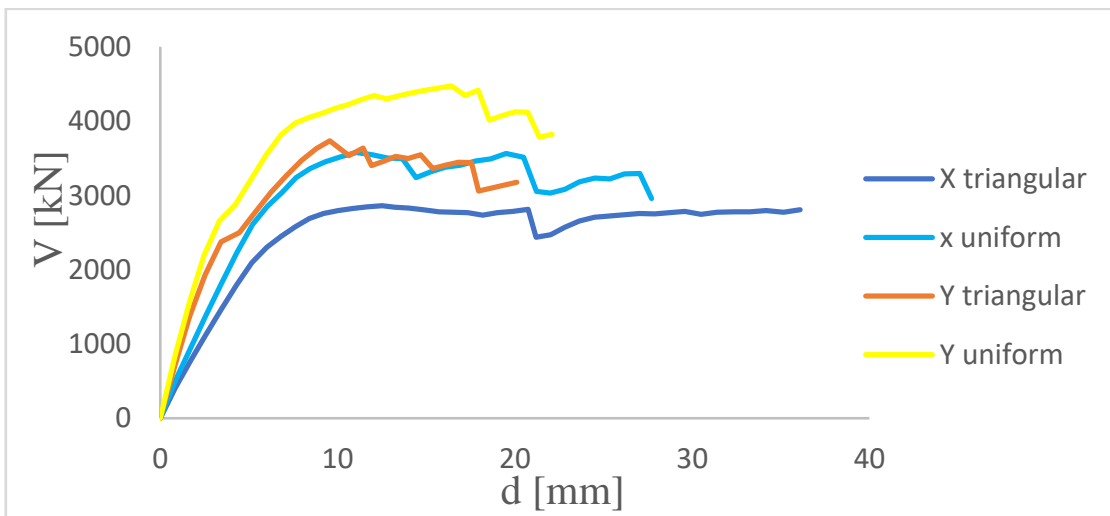

Figure 10. Pushover curves in the two directions for both uniform and triangular load patterns

Based on the results obtained we can notice that the stiffness and strength of the building is a little bit higher in $\mathrm{Y}$ direction. 
On the other hand, the ductility of the system is higher on the X direction. In both directions piers are very slender (due to the opening's configuration) and with a very moderate coupling provided by spandrels. By comparison of the results obtained with the two lateral load patterns, it can be seen how the triangular load pattern is more demanding than the uniform load pattern, since the curves run below the later ones. Figure 11 and Figure 12 shows the damage pattern on the main façade walls of the buildings for the last steps of the pushover analysis. The legend of the figures displays the type of behavior and damage failure in each structural element.

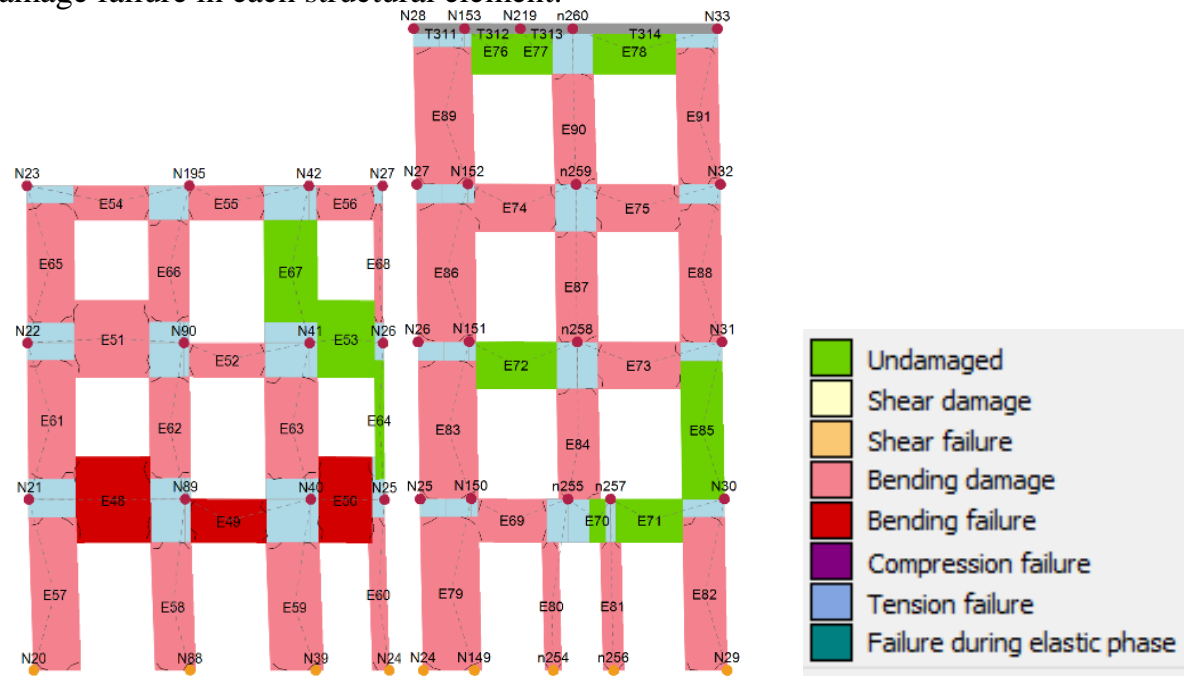

Figure 11. Damage pattern of the main facade with pseudo-triangular load in $X$ direction

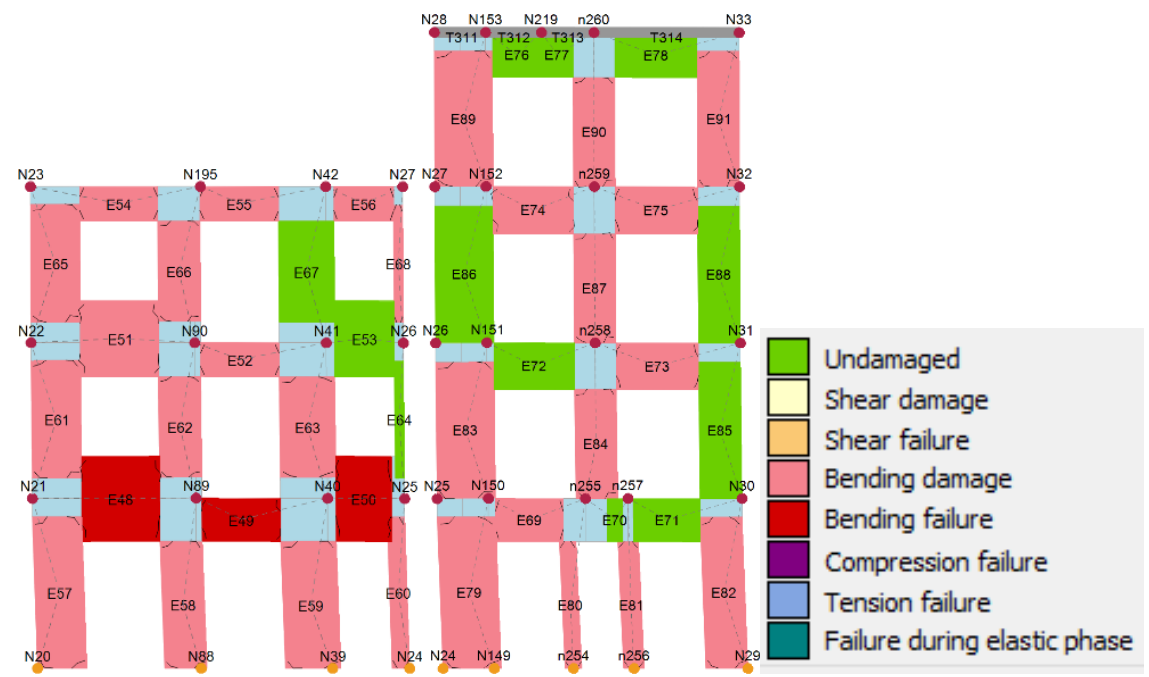

Figure 12. Damage pattern of the main facade with pseudo-triangular load in $Y$ direction 
Contemporary achievements in civil engineering 21. April 2017. Subotica, SERBIA

Timber floors are typically flexible and they were replaced, in agreement with the conservation principle, with new ones to increase their in-plane stiffness that enables the horizontal forces to be redistributed between the failing walls to the adjacent remaining walls, therefore the structure should behave like a box. In this case, the structure has a different behavior because of the connection among different elements and it exhibits a soft story failure mode.

The global structural performance of the structure is affected by the efficiency of floorwall and beam-wall connections.

\section{CONCLUSIONS}

In this paper, a brief description of the typology of "Pombalino" buildings is presented and the results of the seismic assessment, based on nonlinear static procedures, of an existing building, which was structurally strengthened, are discussed. The structure was modelled with the equivalent frame model approach considering 3Muri software, release 10.9.1.7.

The buildings structural capacity curves were found out by incremental nonlinear static (pushover) analysis, neglecting the out-of-plane behavior of the walls (the design code assumes that the global building response is governed by the in-plane behavior of walls). Due to the fact that the global structural performance of the building is affected by the connections among different elements, a further study needs to be done, especially for better understanding the floor-wall, beam-wall connections.

\section{REFERENCES}

[1] Cardoso Rafaela, Lopes Mário, Bento Rita "Earthquake Resistant Structures of Portuguese Old "Pombalino" Buildings" 13th World Conference on Earthquake Engineering, Vancouver, Canada, 2004.

[2] Cardoso R., Lopes M., Bento R., D’Ayala D. "Historic, Braced Frame Timber Buildings With Masonry Infill ("Pombalino" Buildings)", World Housing Encyclopedia Report, Earthquake Engineering Research Institute EERI, www.world-housing.net (Country: Portugal)

[3] Cardoso Rafaela, Lopes Mário, Bento Rita "Seismic Assessment of "Pombalino" Buildings" 13th World Conference on Earthquake Engineering, Vancouver, Canada, 2004.

[4] A2P, Camera Municipal de Lisboa "Specifications" Edifício na rua s. joão da praça nos 29 a 39 - Lisboa projecto de execução de fundações e estruturas, P628-A2PEXE-MD-002-0, Lisbon, 2012.

[5] Simoes A., Bento R., Lagomarsino S., Cattari S. "Seismic Pushover Analysis of 'Gaioleiro' Buuildings in Lisbon" 50SE-EEE 1963-2013 International Conference on Earthquake Engineering, Macedonia, 2013.

[6] Simoes A., Bento R., Lagomarsino S., Cattari S. "Seismic assessment and retrofitting of "Pombalino" buildings by fragility curves" 15 World Conference on Earthquake Engineering, Lisbon, Portugal, 2012. 
Савремена достигнућа у грађевинарству 21. април 2017. Суботица, СРБИЈА

[7] European Committee for Standardization (CEN):" Eurocode 8: Design of structures for earthquake resistance - Part 1: General rules, seismic actions and rules for buildings (EC8-1)" CEN 2004.

[8] European Committee for Standardization (CEN): "Eurocode 8: Design of structures for earthquake resistance - Part 3: Assessment and retrofitting of buildings (EC8-3)" CEN 2005.

[9] Italian Code for Structural Design Norme Tecniche per le Costruzioni - NTC D.M. 14/1/2008, Official Bulletin No 29 of February 4, 2008 (In Italian).

[10] 3Muri Program, S.T.A.DATA s.r.l., release 10.9.1.7 http://www.stadata.com 